\title{
Justyna Gatuszka
}

Uniwersytet Jagielloński, Kraków

\section{UWIEZZIONA AMBICJA}

\section{STARANIA JANA SZCZESNEGO HERBURTA O UWOLNIENIE Z KRAKOWSKIEGO WIĘZIENIA PO ROKOSZU ZEBRZYDOWSKIEGO}

\begin{abstract}
AMBITION IMPRISONED. JAN SZCZESNY HERBURT'S ATTEMPTS TO BE RELEASED FROM PRISON IN KRAKÓW FOLLOWING THE ZEBRZYDOWSKI ROKOSZ
\end{abstract}

The article presents the endeavors of Jan Szczęsny Herburt (1567-1616) to leave the Kraków prison where he was placed after the Battle of Guzów in 1607. These were closely connected with contemporary domestic policy, which was dominated by a conflict between the monarch Zygmunt III Wasa and the Polish-Lithuanian nobility. Herburt was one of the few rokosz leaders to be imprisoned, and the monarch's actions indicated that he wanted to punish the insubordinate noble firebrand.

Key words: Sandomierz rokosz, Zygmunt III Wasa, Guzów, Jan Szczęsny Herburt, propaganda, political leaflets

Słowa kluczowe: rokosz sandomierski, Zygmunt III Waza, Guzów, Jan Szczęsny Herburt, propaganda, pisma polityczne

5 lipca 1607 r. pod Guzowem w ziemi sochaczewskiej w województwie rawskim doszło do starcia między rokoszanami a wojskami królewskimi ${ }^{1}$. Bez wątpienia stanowiła ono punkt kulminacyjny sporu między królem i jego otoczeniem a szlachtą skupiona wokół wojewody krakowskiego Mikołaja Zebrzydowskiego, który to konflikt przeszedł

1 Jedyną monografią tej bitwy jest praca: R.F. Grabowski, Gurów 5 VII 1607 r., Zabrze 2005. 
do historii pod nazwa rokoszu Zebrzydowskiego (1606-1609) ${ }^{2}$. Bitwa guzowska była bezpośrednią konsekwencja wypowiedzenia posłuszeństwa Zygmuntowi III Wazie pod Jeziorną ${ }^{3}$ W starciu zwyciężyło doświadczenie i umiejętności taktyczne dwóch hetmanów w służbie monarchy: polnego koronnego Stanisława Żółkiewskiego i wielkiego litewskiego Jana Karola Chodkiewicza. Oprócz nich po stronie Zygmunta III Wazy walczyli inni zaprawieni w bojach żołnierze: Mikołaj Struś, Aleksander Bałaban, Roman Różyński czy Walenty Kalinowski. Po stronie rokoszan brakowało doświadczonych dowódców, dobrze wyćwiczonego wojska i zdolności współdziałania. Obie strony nie przejawiały również woli walki, nie chciano przelewać bratniej krwi - co pokazuja straty w ludziach. Źródła nie są jednoznaczne w kwestii określenia liczby zabitych, zapewne po stronie królewskiej poległo kilkadziesiąt osób, rannych było około 100, zaś wśród rokoszan było kilkuset zabitych i rannych ${ }^{4}$.

Nieomal nazajutrz po bitwie władca i hetman Żółkiewski wydali uniwersały skierowane do szlachty ${ }^{5}$. Ich celami było podkreślenie królewskiej dobroci i niechęci do dalszego przelewania krwi szlacheckiej, skrytykowanie postępowania rokoszan oraz znie-

2 Rokosz Zebrzydowskiego, mimo swojego znaczenia dla dziejów politycznych Rzeczypospolitej polsko-litewskiej, nie doczekał się jeszcze pełnego opracowania. Pierwszą część rokoszu omówił J. Maciszew ski, Wojna domowa w Polsce (1606-1609), Cressí I. Od Stęzycy do Janowca, Wrocław 1960, Prace Wrocławskiego Towarysstwa Nankowego. Seria A. Poza tym wymienić można artykuły i studia dotyczące zagadnień szczegółowych: m.in. J. Byliński, Rokoszonve koncepcje reformy państwa (1606-1608), [w:] Studia historyczno-prawne. Ksiegga pośniecona pamieci Profesora Jana Seredyki, red. W. Kaczo row ski, Opole 2008; id em, Antyregalistyczna propaganda w czasach rokoszu Zebraydowskiego (1606-1608), [w:] Na obrzeżach polityki, cz. 1, red. M. Kosman, Poznań 2002; E. Opaliński, Dwa nieznane projekty „procesu” konfederacji warszawskiej ₹.1605 i 1607 roku, „Res Historica” 2000, z. 10: Z driejón stosunków ny znanionych w Rzeczypospolitej XVI-XVII wieku, s. 165-177; id em, Zjaz̨d rokoszowy w Jedrzejowie w roku 1607, [w:] Król a prawo stanów do oporu. Materialy konferenci naukowej zorganizowanej przez Zamek. Królewski na Wawelu, Instytut Historii Polskiej Akademii Nank, Instytut Historii Uniwersytetu Jagiellońskiego, Instytut Historii Uniwersytetu Ślaskiego w dniach 4-6 października 2006, red. M. Markiewicz, E. Opaliński, R. Skowron, Kraków 2010, s. 221-236; idem, Zjazd rokoszowy warszawski w październiku 1607 r., [w:] „Kwartalnik Historyczny” 2014, R. 121, s. 521-539; J. Maciszew ski, Sejm 1607 r. a Zatamanie sie planów reformy państwa, [w:] O naprawe Rzeczypospolitej XVII-XVIII w. Prace ofiarowane Wtadystawowi Czaplinskiemu w 60 rocznice urodzin, red. J. Gierow ski et al., Warszawa 1965, s. 37-47; id em, $W$ przededniu bitwy guzonskiej, [w:] $Z$ driejón wojny i polityki. Ksiegga pamiatkowa ku uczczeniu siedemdziesiatej rocznicy urodzin prof. dra Janusza Wolinskiego, red. S. Herbst et al., Warszawa 1964, s. 179-189, Zessyty Naukowe. Seria Historyczna.

3 Do wydarzenia tego doszło 24 VI 1607 r. Przyczyny tego aktu wyjaśniał dokument Wypowiedzenie postuszeństwa Zygmuntowi, królewicowi sz̧wedžkiemu, anno 1607 die nativitatis Ioannis Baptistae, [w:] Pisma polityczne z.çasón rokoszu Zebrayddowskiego 1606-1608, wyd. J. Czubek, t. 3 (Proza), Kraków 1918, s. 349357.

4 A. Pawłowska-Kubik, Od nypowiedzenia postuszeństwa Zygmuntowi III (24 VI 1607) do sejmu pacyfikacyjnego (1609). Rzeczpospolita na politycznym rozdro:zu, praca doktorska napisana pod kierunkiem dr. hab. Tomasza Kempy, prof. UMK, Toruń 2016 (udostępniona dzięki uprzejmości Autorki), s. 181-182.

5 Uniwersał Zygmunta III, z obozu pod Orańskiem 6 VII 1607, Archiwum Narodowe w Krakowie [dalej cyt.: ANK], Archiwum Sanguszków [dalej cyt.: A. Sang.], teka XXVII, koperta 28, s. 193-196; uniwersał S. Żółkiewskiego do żołnierzy rokoszowych, około 12 VII 1607, [w:] Pisma Stanisława Źótkienskiego kancleræa koronnego i hetmana, wyd. A. Bielow ski, Lwów 1861, s. 473-474; uniwersał S. Żółkiewskiego do 
chęcenie społeczeństwa do popierania ruchu antyregalistycznego, pod groźbą surowych kar. Strona przeciwna nie mogła pozostawić ich bez odpowiedzi, rozpoczęła się zatem walka propagandowa i rywalizacja obu obozów politycznych. Mikołaj Zebrzydowski i Janusz Radziwiłł, ówczesny podczaszy litewski, podjęli decyzję o kontynuowaniu walki, kierując się głównie deklaracjami swoich żołnierzy. Rozesłali listy do szlachty i uniwersał zapowiadający wolną elekcję̨. Jednocześnie poszczególni rokoszanie próbowali przygotować się do rozmów z królem, wyrażając chęć współpracy i pojednania. Świadczy o tym m.in. poselstwo do kasztelana krakowskiego Janusza Ostrogskiego ${ }^{7}$. Relacjonował on Żółkiewskiemu przebieg dyskusji „o naprawie praw i swobód naruszonych”, zaś konsekwencją ewentualnego porozumienia w tej kwestii miało być cofnięcie aktu detronizacji ${ }^{8}$. Rokoszanie zaproponowali powołanie wspólnej deputacji dla przezwyciężenia kryzysu wewnętrznego, ale ewentualne porozumienie z władca pragnęli opatrzeć własnymi warunkami. Niechętnie do tych propozycji odnosił się hetman polny. Uważał on, że jedynym sposobem na rozwiązanie konfliktu w państwie jest zwołanie sejmu. Zalecał zatem kasztelanowi krakowskiemu ostrożność podczas takich rozmów, gdyż mogły być one jedynie fortelem rokoszan, dzięki któremu zyskaliby czas na zgromadzenie nowych sił i środków na kontynuowanie walki'.

Jednocześnie dzień po bitwie rozpoczęła się pogoń za rokoszanami, która jednak nie przyniosła spodziewanych efektów ${ }^{10}$. Jednym z nielicznych pojmanych był Jan Szczęsny Herburt (1567-1616) - starosta dobromilski, mościcki i wiszeński, sekretarz królewski, pisarz polityczny w okresie rokoszu Zebrzydowskiego, poeta, poseł na sejmy walne oraz dyplomata ${ }^{11}$. W niniejszym artykule chciałabym przedstawić okres jego niewoli, a przede wszystkim starania Herburta i jego bliskich o uwolnienie go z więzienia, do którego trafił w 1607 r. Związane jest to ściśle z ówczesną polityką wewnętrzną Rzeczypospolitej, która w tym czasie koncentrowała się wokół próby sił między królem a społeczeństwem szlacheckim. Problem ten nie spotkał się do tej pory z należytą uwagą historyków, a bez

szlachty, z obozu pod Krasnymstawem 12 VII 1607, [w:] ibidem, s. 475-477; S. Żółkiewski do lubelskiej, chełmskiej i bełskiej, z obozu pod Krasnymstawem 17 VII 1607, [w:] ibidem, s. 477-479.

6 A. Pawłowska-Kubik, op. cit., s. 200.

7 S. Lubieński, Droga do Szwecji Zygmunta III, króla polskiego i sz̨wedžkiego, w 1593 roku. Rozruchy domowe $w$ Polsce w latach 1606-1608, przel. A.B. Jocher i S. Szczygieł, wyd. J. Byliński, W. Kaczorowski, Opole 2009, s. 161-162.

8 J. Ostrogski do S. Żółkiewskiego, Opatów 20 VII 1607, [w:] Pisma Stanisława Żótkiewskiego..., s. 480.

9 Ibidem, s. 482-483.

10 Z wieloma rokoszanami łączyły Żółkiewskiego więzi przyjaźni czy powinowactwa, niechętnie więc kierował tą akcja, skupiając się głównie na rozsyłaniu uniwersałów, zaś podkomendnym zlecając ściganie buntowników. Por. A. Cilli, Historia buntón możnowtadcsych w Polsce w latach 1606-1608. Historia Moskewy, przeł. A. Broczkowska-Nguyen, oprac. i wyd. J. Byliński, W. Kaczorowski, Opole 2012, s. 115.

11 S. Cynarski, Herburt Jan Szczesny h. własnego (1567-1616), [w:] Polski stownik biograficzny [dalej cyt.: PSB], t. 9, Wrocław 1960-1961, s. 443-445. 
wattpienia zasługuje na bliższą analizę, gdyż pozostali liderzy ruchu antykrólewskiego, odczekawszy kilka tygodni w ukryciu po bitwie pod Guzowem, pozostali wolni. W przypadku Szczęsnego okazało się, że król nie zamierzał poprzestać na karze więzienia, ale podjał starania o skazanie na śmierć szlacheckiego „warchoła”.

Udział Herburta w bitwie pod Guzowem nie stanowił dla niego powodu do dumy. Podczas samego starcia znajdował się on na prawym skrzydle (pod jego rozkazami było ok. 1000 ludzi) i miał przed sobą wojska Stanisława Żółkiewskiego. W trakcie bitwy oddziały Herburta uległy całkowitej panice i się rozproszyły. Wszystko wskazuje na to, że w momencie zetknięcia się z wojskiem królewskim Herburt natychmiast się wycofał. Nie przysporzyło mu to popularności, powstawały utwory literackie wytykające mu tchórzostwo, m.in. W Jana Szczesnego Herburta uciekajacego z bitwy ${ }^{12}$. W przeciwieństwie do innych rokoszan nie ukrył się, lecz udał się pod Lublin, gdzie wraz z Januszem Radziwiłłem wspólnie gromadzili żołnierzy i pieniądze, nakładając kontrybucje na kupców ${ }^{13}$. Po kilku dniach, 18 lipca, Herburt został pojmany przez Mikołaja Strusia w Tajkurach (wieś w okolicach Ostroga), następnie osadzony w Krakowie w sierpniu 1607 r. ${ }^{14}$ Tę niedolę przyszło mu dzielić z Prokopem Pękosławskim ${ }^{15}$, który nie należał do grona przywódców rokoszu. Zarówno wojewoda krakowski Mikołaj Zebrzydowski, jak i kasztelan wileński Janusz Radziwiłł uniknęli więzienia. Nie są jasne przyczyny uwięzienia Herburta i Pękosławskiego oraz skazania ich na śmierć, gdyż nie przedstawiono ich opinii publicznej. Zapewne głównymi powodami więzienia i decyzji o tak wysokiej karze była obraza majestatu królewskiego i intrygi z obcymi monarchami. Możemy domniemywać, że strona królewska chciała wykorzystać w oskarżeniu wszystkie obraźliwe wystąpienia na zjazdach szlacheckich, których autorem był Herburt, oraz zakłócanie przez niego pracy Trybunału Koronnego w Lublinie ${ }^{16}$. O ile to ostatnie oskarżenie można było obalić, pojawiający się zarzut zdrady stanu był o wiele poważniejszy. Dowodem winy Herburta miała być korespondencja z księciem siedmiogrodzkim Gabrielem Batorym w sprawie objęcia polskiego tronu, odnaleziona po bitwie guzowskiej ${ }^{17}$. Istnienie owych

12 Pisma polityçne..., t. 1, Kraków 1916, s. 233-234.

13 Biblioteka Narodowa [dalej cyt.: BN], 3087, Relacja z Lublina, k. 616.

14 Anonimowy autor Genuina revificatio calamitatis Polonae w następujący sposób opisuje te wydarzenia: [...] „na Herburta Szczęsnego, na dom pana wojewody wołyńskiego, ojca żony jego, nasławszy wojsko, samego usieczonego wzięto, żonę odarto, zelżono, dwór spalono, związanego do Krakowa wieziono i teraz w więzieniu go trzymają...", [w:] Pisma polityczne..., s. 390-391.

15 W. Biliński, M. Lipko, Pekosławski Prokop h. Abdank (zm. po lutym 1609 r.), [w:] PSB, t. 25, Wrocław 1980, s. 740-742.

16 Por.: M. Dyjakow ska, Naruszenie bezpieczeństwa obrad Trybunału Koronnego jako „crimen laese maiestatis”, [w:] Trybunat Koronny w kulturze prawnej Rzecsypospolitej sqlacheckiej, red. W. Bed naruk, A. Dębiński, M. Lipska, Lublin 2008, s. 113-129.

17 „Na placu bitwy znaleziono podarte listy Gabriela Batorego, księcia Transylwanii, do Herburta. Batory wyraził w nich zgodę na przejęcie władzy w królestwie, gdy z tronu zostanie usunięty obecny król. Pismo 
listów nie zostało w historiografii rozstrzygnięte ze względu na niespójność źródeł. Te kategorie przestępstw podlegały orzecznictwu sądu sejmowego, w wypadku oskarżenia o zdradę stanu odpowiadano przed królem, senatorami i ośmioma przedstawicielami izby poselskiej, zaś obrazę władcy sądzono w składzie pomniejszonym o osobę monarchy ${ }^{18}$. Kolejny sejm, na którym mógł się odbyć taki sąd, miał miejsce w 1609 r., a decyzja o postawieniu buntowników przed sądem sejmowym zapadła podczas konwokacji krakowskiej w 1608 r. Ta niekonsekwencja rodzi liczne pytania: w jaki sposób została podjęta decyzja o osądzeniu i skazaniu Herburta oraz Pękosławskiego? Czy z powodu niespokojnej sytuacji wewnętrznej w kraju doszło do tak istotnego naruszenia porządku prawnego? Henryk Wisner sugerował, że być może król miał w tej sprawie większe możliwości karania niż te wyznaczone przez prawo ${ }^{19}$. Jest to trudne do wyobrażenia w ówczesnej sytuacji Rzeczypospolitej i przy stosunku szlachty do przestrzegania jej praw i przywilejów przez monarchów. Być może te decyzje Zygmunt III podją podczas kilkutygodniowego okresu pozornego spokoju w kraju, kiedy szlachta bacznie obserwowała jego ruchy oraz postępowanie wobec rokoszan.

Starosta dobromilski, przerażony determinacją króla, postanowił uczynić wszystko, by uratować swoje życie i odzyskać wolność. Słał listy adresowane do krewnych i przyjaciół, osób wpływowych oraz pozostających w otoczeniu władcy. Wyrażał w nich skruchę za swoje czyny i prosił o wstawiennictwo u monarchy. Sytuacja stawała się dramatyczna, gdyż pomocy odmówił mu teść, książę Aleksander Zasławski, wojewoda wołyński, oraz krewny Jerzy Zbaraski, wcześniej blisko związany z buntownikiem, a obecnie posiadający duże wpływy w otoczeniu króla ${ }^{20}$. Niestety nie znamy wszystkich listów Herburta i Zbaraskiego. Szczęsny do swojego przyjaciela skierował na pewno dwa pisma: treść pierwszego nie jest znana, dowiadujemy się o nim jedynie z niedatowanej odpowiedzi

i podpis z pewnością należały do Batorego, nie było zatem żadnej wątpliwości, kto w rzeczywistości stał za tymi planami. Herburt był przecież krewnym i biskim przyjacielem wojewody krakowskiego. Uważano więc, że to właśnie Herburt i wojewoda wyznaczyli na nowego króla Batorego, mimo iż był on heretykiem”, za: S. Lubieński, Droga do Szwecji..., s. 157. Wspominał o owych listach również S. Żółkiewski w uniwersale do szlachty: „czekaja [rokoszanie - przyp. J.G.] aby fundament wolności naszej wolnej elekcyej z gruntu wywrócili i bez nas pana koronowanego złożywszy, inszego ku wiecznemu zniewoleniu naszemu nam wedle myśli wydali, o czym listy ich jakie z cudzoziemskiemi pany praktykowali”, [w:] Pisma Stanistawa Źótkiewskiego..., s. 476.

W. Zarzy cki, Temida sejmowa. Z dziejón sqdu sejmowego w Polsce przedrozbiorowej, Warszawa 2000, s. 14.

H. Wis ner, W imie praw i zanyczajón, cayli wbrew nim. Rokosz Zebraydowskiego 1606-1607, [w:] Król a prawo..., s. 218.

20 Szerzej o stosunkach Herburta i Zbaraskiego: W. Dobrowolsk a, Mtodość Jerzego i Krayysztofa Zbaraskich (Ze wstepem o rodzie Zbaraskich $i$ sycciorysem Janusza Zbaraskiego wojewody bractawskiego), „Rocznik Przemyski”, t. 7, Przemyśl 1927, s. 174-182. Istotna dla poznania relacji między tymi postaciami jest również edycja korespondencji J. Zbaraskiego: A. Filipczak-Kocur, Korespondencja Kraysztofa ksiecia Zbaraskiego koniuszego koronnego 1612-1627, Opole 2015. 
adresata $^{21}$, drugie zaś poddane zostanie tutaj szerszej analizie ze względu na swoje znaczenie dla przedstawianego tematu ${ }^{22}$. Zbaraski w liście do Herburta tłumaczył się, że po przemyśleniu całej sytuacji nie może wstawić się za nim u króla ${ }^{23}$. Chwalił jego dobre urodzenie, wychowanie i wykształcenie, jednak nie ukrywał, że wina starosty jest oczywista, czego najdobitniejszym przykładem było odwrócenie się najbliższych od niego. Zbaraski sugerował, że jego wstawiennictwo mogłoby jeszcze bardziej zaognić konflikt między uwięzionym a Zygmuntem III. Stwierdzał również, że próba obrony Herburta, czołowego antyregalisty, sprowadziłaby na niego pośmiewisko ${ }^{24}$. Być może, jak sugeruje Wanda Dobrowolska, Zbaraski obawiał się o swoją karierę na dworze królewskim $^{25}$. Kończąc swój list, zalecał przyjacielowi zachowanie spokoju i oczekiwanie na uspokojenie sytuacji w kraju ${ }^{26}$. Asekuranctwo ze strony Zbaraskiego nie zniechęciło Szczęsnego. W swojej odpowiedzi dziękował za słowa uznania i wsparcia, sam nie pozostając dłużnym:

Panu Bogu dziękuję, że takim poznawam WKsMć, jakim dawno rozumiałem i z urodzenia zacnego i z ćwiczenia przedniego i z powinowactwa niedalekiego i z towarzystwa wdzięcznego, bom dotąd rozumiał, że już w Polszcze Polaków nie masz ${ }^{27}$.

Wyjaśniał w liście powody przystapienia do rokoszu, wynikające z troski o ojczyznę i chęć wypracowania kompromisu między szlachtą a królem. Podkreślił jednocześnie, że cierpiał od braci szlachty „niechęci i przymówek niemało" 28 . Sugerował również, że odwrócenie się od niego jego bliskich to wynik pomyłki: teść, książę Zasławski, został wprowadzony w błąd przez Stanisława Żółkiewskiego, ale nieporozumienie zostało już wyjaśnione i wojewoda wołyński podjął starania o uwolnienie zięcia, m.in. pisząc list do kardynała Bernarda Maciejowskiego ${ }^{29}$. Ponawiał jednocześnie prośby o wstawien-

21 Przedruk w: Korespondencja Jeræego Zbaraskiego, [w:] „Scriptores Rerum Polonicarum”, t. 5 (dalej: SRP), wyd. A. Sokołows ki, Kraków 1880, s. 159-160; również w Bibliotece Książąt Czartoryskich [dalej cyt.: B. Czart.] 1577, k. 189. Prawdopodobnie list powstał ok. 20 V 1608 r. Wskazują na to słowa: „Przyjdzie podobno WMości poczekać uspokojenia Rzptej, które bodaj prędko było”. Zapewne Zbaraski ma tu na myśli konwokację krakowską 24 IV 1608 r.

22 L. Szczerbicka, Jan Szczesny Herburt. Zarys monografii, [w:] Ze studión nad literatura staropolska, red. K. Budzyk, Wrocław 1957, s. 249, Studia Staropolskie.

23 Do Szczęsnego Herburta, b.m. i d., „SRP”, t. 5, s. 159.

24 Ibidem, s. 160.

25 W. Dobrowolska, op. cit., s. 178.

26 Do Szczęsnego..., s. 160.

${ }^{27}$ Respons Xciu JMci od JM Pana Herbortha, b.m. i d., B. Czart., 1577, k. 192.

28 Ibidem, k. 192.

29 Ibidem. 
nictwo, zapewniając o swoich dobrych intencjach i poczciwości, kreując się na „dziwnie utrapionego szlachcica"30. Przysięgał również, że słusznie Zbaraski podkreśla jego wykształcenie, wychowanie, zasługi rodziny i wiarę chrześcijańską ${ }^{31}$.

Niewątpliwym wsparciem dla Herburta była jego małżonka Elżbieta z Zasławskich, która w 1608 r. przybyła do Krakowa wraz z potomstwem. Wspólnie napisali dwa listy do najważniejszych kobiet w otoczeniu króla: królowej Konstancji ${ }^{32}$ oraz siostry Zygmunta III Anny Wazówny ${ }^{33}$. Prosili w nich o wstawiennictwo u władcy, by ten zgodził się „do łaski i ręki swej Pańskiej dać przystęp”34. Miało to utwierdzić sławę Zygmunta III jako króla miłosiernego i łaskawego dla swoich poddanych, zaś wstawiennictwo małżonki oraz siostry powinno naturalnie wynikać z ich dobroci. W podpisie pojawia się określenie „kochający”, poprzedzając podpis więźnia i jego „małżonki najmilszej”’35. Było to bardzo dobre posunięcie, ze względu na wpływ obu niewiast na decyzje królewskie. Przy okazji widać wyraźnie desperację Herburta i rzeczywistą obawę o własne życie.

Nietuzinkowym działaniem ze strony starosty było nawiązanie kontaktu z Marcinem z Kłecka, wróżbitą i astrologiem ${ }^{36}$. Pozostawiając swój list bez podpisu i zdradzania swojej tożsamości, prosił o stworzenie dla siebie horoskopu:

Iż do ciebie piszę sprawiła sława Twoja, którą́s sobie zjednał rozsądkiem w roku teraźniejszym [...] abyś nie oglądając się na żadną rzecz, tym bezpieczniej, jako nie wiedząc komu, wszystko wyraził, co divina twoja mens znajdzie: vitia, virtutes, bona, adversa. Iż upominek mały posyłam o wielką rzecz prosząc, non sum dualis eram ${ }^{37}$.

Dalszą współpracę między nimi opisał w swoim pamiętniku Albrycht Stanisław Radziwiłł. Pokładane we wróżbicie nadzieje się nie spełniły. Marcin obiecał Herburtowi wyzwolenie, polecając mu ucieczkę przez komin. Radziwiłł podaje, że dzięki staraniom żony czarnoksiężnik miał pojawić się w więzieniu, zastrzegł jednak, iż Szczęsny nie może wezwać ani razu imienia boskiego. Zdesperowany więzień usłuchał rady,

\section{Ibidem, k. 193.}

31 Ibidem.

32 B. Czart., 104, Suplika Pana Szczęsnego Herbortha w Krakowie z więzienia Królowej Jejmości podana, 1608 r., k. 585.

33 Ibidem, Suplika druga do królewny tej mci szwedzkiej, 1608 r., k. 581-582.

34 Ibidem, k. 581.

35 Ibidem, k. 582.

36 Marcin z Kłecka był znanym pisarzem religijnym na przełomie XVI i XVII w., autorem traktatów medycznych, astrologiem i wróżbita. Szerzej zob.: D. Jung, Wierszopisowie Klecka w latach 1590-1623. Praysczynki do historii kultury staropolskiej, Kłecko-Gniezno 2012, Biblioteka Staropolska, t. 1.

37 B. Czart., 1577, J.S. Herburt ad Martinum Mathematicum Clecensam ex vinculis Cracoviensis, k. 203205. 
[...] lecz w części górnej komina, gdzie wyżej było, a brzuch wielki wyjściu przeszkadzał, wykrzyknął Herburt, wzywając na pomoc imienia boskiego, wtem znikł czarownik i zostawił go w kominie ${ }^{38}$.

Z opresji uratowała go straż więzienna, która podczas poszukiwań więźnia odkryła, że niedoszły uciekinier zaklinował się w kominie. Oczywiście współcześnie patrzymy na te poczynania z rozbawieniem, jednak dla Herburta było to upokarzające rozczarowanie.

Podczas pierwszych miesięcy więzienia starosta działał chaotycznie, za wszelką cenę starając się dotrzeć do króla przez wstawiennictwo bliskich mu osób. Niepewność sytuacji skierowała go również ku astrologii i przepowiadaniu przyszłości. Po tragikomicznej próbie ucieczki z krakowskiego więzienia pozostał jedynie wstyd oraz kolejny cios w już i tak nadwyrężoną ambicję Szczęsnego. Jedynym sukcesem tego czasu była zgoda Zygmunta III na zaniechanie wykonania kary śmierci na rokoszaninie. Jak pisze Paweł Piasecki, stało się to za sprawą marszałka wielkiego koronnego Zygmunta Myszkowskiego $^{39}$, „który wykonanie tego wyroku dopóty zwlekał, póki się król przebłagać nie dał" "40. Działania marszałka nie wynikały z osobistej sympatii do Herburta, który był częstym celem jego ataków w publicystyce rokoszowej, a raczej z czystej pragmatyki ${ }^{41}$. Obawiał się on ściagnięcia na siebie nienawiści społeczeństwa za uśmiercenie popularnego i lubianego szlachcica. Jako znany regalista oraz bliski współpracownik króla mógł również zaszkodzić tym władcy ${ }^{42}$. Ponadto w społeczeństwie nadal żywa była pamięć o Samuelu Zborowskim, zaś niespokojna sytuacja w kraju groziła kolejnym wybuchem, gdyby król dążył do pokazania swojej siły w sporze z rokoszanami.

Jesienią 1607 r. w Rzeczypospolitej pojawiły się pierwsze głosy wzywające króla do uwolnienia Herburta i Pękosławskiego. Wstawili się za nimi biskupi podczas synodu w Piotrkowie ${ }^{43}$. Podkreślili oni pochodzenie Herburta z bardzo szanowanej i zasłużonej dla Rzeczypospolitej rodziny. W uznaniu ich zasług dla państwa i Kościoła wspomniani

38 A.S. Radziwiłł, Ryspanowania Zygmunta III, wyd. J. Byliński, W. Ka czorowski, Opole 2011, s. 53.

39 U. Augus tyniak, Myszkowski (Myszkonski-Gonzaga margrabia na Mirowie) Zygmunt b. Jastrzebiec udostojniony (ok. 1562-1615), [W:] PSB, t. 22, Warszawa 1977, s. 404-407.

40 P. Pia secki, Kronika Pawła Piaseckiego biskupa przemyślskiego, wyd. J. Bartoszewicz, Kraków 1870 , s. 212.

41 Z. Myszkowskiego w publicystyce rokoszowej przedstawiano bardzo negatywnie. Obarczano go winą za utratę lenna pruskiego, oskarżano o przyjmowanie korzyści majątkowych i sprzyjanie Habsburgom. W jednym z utworów został opisany w sposób następujący: „Lecz skądże się Gowzaga w Polsce zjawił, a gdzież się na ten cudzoziemski tytuł zdobył, godzienby z swym tytułem w sztuki rozsiekania, abo na wieczną pamięć z Korony wygnania...", Elegia posłów splondrowanych od pogan, [w:] Pisma polityczne..., t. 1, Kraków 1916, s. 3.

42 Ibidem.

43 B. Czart., 341, List przyczynny do Króla JMci od Synodu za Imcią P. Herburtem, Piotrków, 15 X 1607 r., s. $898-899$. 
zostali ojciec ${ }^{44}$ i stryj ${ }^{45}$, o których pamięć nadal była żywa w społeczeństwie szlacheckim. Duchowni wskazywali władcy, że również Jan Szczęsny może być jeszcze przydatny dla kraju. Za Herburtem ujął się także poeta Kasper Miaskowski ${ }^{46}$, który w wierszu Do JMP

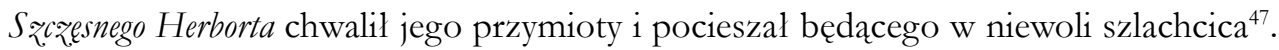
Było to o tyle zaskakujące, że ten dosyć popularny literat jeszcze nie tak dawno, w czasie trwania rokoszu, prowadził polemikę z Herburtem. Napisał wówczas Apologie na paszkwil przeeciwleo KJMć naz̧byt bystrze i wszetecznie pisany ${ }^{48}$, stanowiącą obronę króla i odpierająca zarzuty zawarte w utworze Sumnienie mówi, który przypisywany jest Szczęsnemu. We wcześniejszej literaturze zastanawiano się nad przyczynami tego nieoczekiwanego wsparcia dla rokoszanina ze strony zwolennika Zygmunta III ${ }^{49}$. Być może Miaskowski spodziewał się, zresztą słusznie, iż Herburt odwdzięczy się za pomoc w tak trudnym dla niego momencie ${ }^{50}$. Poeta poświęcił mu również utwór Herkules niecierplinwy ${ }^{51}$. Poemat przedstawia rozmowę bogów: Apollina i Merkurego. Dyskutują oni o człowieku wywodzącym się ze znakomitego rodu, o wspaniałym umyśle, który ponad wszystko miłuje wolność i cnoty obywatelskie, ale „domowe wiatry mu zagnały nieszczęsny okręt miedzy ostre skały"52. Mowa wprost o Herburcie, gdy opisywane sa jego podróże zagraniczne, wykształcenie i zasługi dla kraju (m.in. poselstwo do Porty Ottomańskiej w 1598 r. $)^{53}$. Pod licznymi metaforami kryje się przesłanie dla rokoszanina, by cierpliwie oczekiwał

${ }_{44}$ Jan Herburt (1524-1577) - kasztelan sanocki i starosta przemyski, historyk, prawnik i humanista. Napisał m.in. Historie Polski po łacinie oraz Statuta Regni Poloniae. Zob. R. Żelew ski, Jan Herburt h. własnego (15241577), [w:] PSB, t. 9, Wrocław 1960-1961, s. 441.

45 Walenty Herburt (1524-1572) - biskup przemyski, przedstawiciel Rzeczypospolitej na soborze trydenckim w 1562 r. Przeciwnik reformacji, opiekun zakonu jezuitów. Zob. S. Cynarski, Walenty Herburt h. wtasnego (1524-1572), [w:] PSB, t. 9, s. 453-454.

46 Kasper Miaskowski (1549-1622) - polski poeta barokowy, regalista, ale sympatyzował z Herburtem, który był jego mecenasem. Napisał kilka utworów związanych z rokoszem Zebrzydowskiego. Jego najsłynniejsze dzieła składają się na Zbiór rytmów, Kraków 1612, zob. Bibliografia Literatury Polskiej - Nony Korbut, t. 2, Pismiennictwo Staropolskie, red. R. Pollak, Warszawa 1964, s. 515-516.

47 K. Miaskowski, Do JMP Szczęsnego Herborta, [w:] idem, Zbiór rytmów, wyd. K.J. Turowski, Kraków 1861, s. 172.

48 K. Miaskowski, Apologia na pasそkewil przeciwno KJMć nazbyt bystrze i wszetecznie pisany, [w:] Pisma politycznne..., t. 1, Kraków 1916, s. 24-33.

49 Por. L. D ziama, Zapatrywania polityczne Kaspra Miaskowskiego (na podstawie jego „Rytmów”), „Roczniki Towarzystwa Przyjaciół Nauk Poznańskiego" 1895, t. 21, s. 107-124; A. Sokołow ski, Jan Szczesny Herburt, pierwsyy mydawca Kroniki D tugoszowej, „Biblioteka Warszawska” 1883, t. 2-3.

50 W późniejszych latach w Dobromilu, w drukarni Herburta, drukowane były utwory K. Miaskowskiego, np. Herkules stowieński, Dobromil 1612.

51 Herkules niecierpliny albo rozmowa Apollina z. Merkuryjuszem na gadke Hryca z. Fortuna napisana od JM pana Szczesnego Herborta, [w:] K. Miaskowski, Zbiór rytmów, wyd. A. Nowicka-Jeżowa, Warszawa 1995, s. 213-221.

52 Ibidem, s. 214.

53 Ibidem, s. 215. 
odmiany losu, wierząc w swoje męstwo i rozum, a będzie wówczas „szczęśliwszy po tym w każdej swojej sprawie" 54 .

Niewątpliwie zainteresowanie losem rokoszanina musiało dać mu nadzieję na szybkie opuszczenie więzienia i szansę na rehabilitację. W połowie 1608 r. zarówno Pękosławski, jak i Herburt postanowili wytłumaczyć swoje racje w korespondencji i pismach rozesłanych do znaczących postaci w Rzeczypospolitej. Pękosławski skierował list do biskupa krakowskiego Piotra Tylickiego ${ }^{55}$. Na wstępie dziękował mu za udzielone wsparcie i wstawiennictwo u króla w jego sprawie. Zaznaczał, że nie rozumie powodów swojego uwięzienia, wszak występował jako przedstawiciel szlachty województwa sandomierskiego, a jego celem nie była obraza Zygmunta III, a jedynie naprawa Rzeczypospolitej. Wyrażał chęć przeproszenia „Króla Jegomości” i ofiarowania mu swych usług, zgodził się również na zakaz uczestniczenia w życiu politycznym, gdyż był już stary i chciał zaznać trochę spokoju. Kończył swój list stwierdzeniem, że dotrzyma wszelkich zobowiązań wobec króla ,jako pościwy człowiek" ${ }^{\prime 56}$.

Spod ręki jego więziennego współtowarzysza wyszedł utwór pt. Pismo P. Sžrzesnego Herbulta [sic!], za którym chciał być z wiezienia wolny $1608 r^{57}$ Stanowiło ono nie tylko próbę jego rehabilitacji, ale również swego rodzaju refleksję nad stanem państwa, sposobem sprawowania rządów etc. Herburt rozpoczął swoje pismo od podkreślenia zmienności losu oraz powtarzalności pewnych zjawisk i wydarzeń. Nazwał to circulum politicum. Jego zdaniem właśnie z tym mieliśmy do czynienia w Rzeczypospolitej w 1608 r. Popierał to przykładami z historii powszechnej, zarówno antycznej, jak i nowożytnej ${ }^{58}$. Analizował również sposoby sprawowania rządów. Niczym Niccolò Machiavelli pisał o roli miłości i strachu w rządzeniu państwem, jednak nie podzielał zdania Florentczyka, że „bezpieczniej jest lęk niż miłość sprawiać” ${ }^{59}$. Herburt stał na stanowisku, iż „trwalsza nierówno miłość niż bojaźń” ${ }^{60}$. Była to dosyć oczywista przestroga dla Zygmunta III, który w dobie „powszechnego albo większej części ludzi poruszenia” mógł sobie zjednać miłość poddanych na dwa sposoby, przez „urzędu nowego postanowienie” lub „swobód nowych poczynienie" ${ }^{\prime 1}$. Wyrażał również przekonanie, iż rzeczy publiczne opierają się

$54 \quad$ Ibidem, s. 221.

55 List pana Pękosławskiego z więzienia do ks. biskupa krakowskiego, b.m. i d. [1608 r.], [w:] Listy staropolskie z.epoki Wazón, oprac. H. Malewska, Warszawa 1959, s.77.

56 Ibidem.

57 Pismo p. Sžrzesnego Herbulta, za którym chciał być z. więienia wolny 1608 r., [w:] Listy staropolskie..., s. 79-85. Edycja na podstawie kopii: B. Czart., 1577, Pismo p. Szzzesnego Hetburta, za którym cbciał być z wiezienia wolny, k. 207-211.

58 Pismo p. Szrzesnego Herbutta..., s. 80.

59 N. Machiavelli, Ksiaż, przeł. C. Nanke, Warszawa 1999, s. 65.

60 Pismo p. Szrzesnego Herbutta..., s. 81.

61 Ibidem. 
na prywatnych, dobro wspólnoty i jednostki były dla niego tożsame. Jednocześnie nie dostrzegał potencjalnych zarzewi konfliktu ${ }^{62}$. Wprost sugerował, że jeśli król wykaże się dobrotliwością i łaskawością dla rokoszan, którzy przecież mieli na myśli jedynie dobro kraju, to burzliwe nastroje w społeczeństwie ulegną uspokojeniu i wyciszeniu ${ }^{63}$. Kolejny fragment poświęcony został bezsensowności uwięzienia Herburta i Pękosławskiego. Ich dalsze więzienie określone zostało jako „żagiew najsposobniejsza do zapału”“4.

Być może na zastosowanie takich bezpośrednich zwrotów zdecydował się Herburt po stwierdzeniu, że w kraju ciagle pobrzmiewają echa rokoszu, a sytuacja nie jest całkowicie opanowana ${ }^{65}$. Dzięki temu utworowi kreował się na zatroskanego o dobro ojczyzny szlachcica, który pragnął służyć dobrą radą swojemu władcy. Niewątpliwie uwolnienie buntowników przyczyniłoby się, jego zdaniem, do uspokojenia nastrojów społecznych. Składał również, podobnie jak Pękosławski w liście do Tylickiego, obietnice posłuszeństwa i wierności królowi: „A my będąc dobrymi, jakośmy są, i żaden o nas inaczej rozumieć nie może, do uspokojenia za oświadczeniem dobrotliwości KJMci wiele pomóc możemy" ${ }^{66}$. Podsumowywał również swoje osiagnięcia i działalność na rzecz kraju: chęć przysłużenia się ojczyźnie i zyskania „sławy uściwej”67. Opisywał swoją współpracę z kanclerzem wielkim koronnym Janem Zamoyskim oraz swoje poświęcenie, również finansowe, w czasie misji dyplomatycznych do cesarza czy do Porty Ottomańskiej ${ }^{68}$. Konkludował swój wywód radą do Zygmunta III: „Przeciwko uniwersałom dobrotliwość, przeciwko zjazdom miłość, przeciwko wojskom niewinność. A poddanym zdjąć okowy z nóg, a założyć na serce" ${ }^{\text {"99 }}$.

W utworze tym uderza ogromna duma Herburta. Nie poczuwa się on do żadnej winy, wręcz kreuje się na poszkodowanego całą tą sytuacją. Przecież tyle lat poświęcił służbie dla ojczyzny. Nie wspominał oczywiście o swoich licznych konfliktach z sąsiadami, pomijał utwory publicystyczne doby rokoszu, w których częściej atakował monarchę i jego otoczenie, niż objaśniał problemy ustroju Rzeczypospolitej oraz sposoby na ich rozwiązanie. $Z$ tego elaboratu przebija przeświadczenie o własnej wielkości, pozycji zajmowanej w społeczeństwie szlacheckim oraz o możliwościach oddziaływania na ,panów braci”, którzy gotowi są do dalszej walki, nie tylko słownej.

\footnotetext{
Ibidem.

63 Ibidem, s. 82.

64 Ibidem, s. 83.

65 P. Pias ecki, op. cit., s. 214.

${ }_{66}$ Pismo p. Szczesnego Herbulta..., s. 83.

67 Ibidem, s. 84.

68 Ibidem.

69 Ibidem, s. 85 .
} 
Rozprawa ta nie mogła pozostać bez odpowiedzi Zygmunta III. Monarcha w jednym z pism zalecał Szczęsnemu, by zdał się na osąd senatorów świeckich: „Daj, proszę, na bracią swą sæcularis, bo gdzieżby w nich nie miała zostać chęć i miłość ku WMci koledze swemu" "70. Informował również o staraniach biskupów, które niewątpliwie pozytywnie wpłynęły na króla. Podkreślał pochodzenie Herburta ze znakomitej rodziny, bardzo zasłużonej dla kraju ${ }^{71}$. Uspokajał go również sugestią, że senatorowie będą z cała powagą traktować zarówno prawa Rzeczypospolitej, jak i godność starosty dobromilskiego ${ }^{72}$.

Wydawać by się mogło, że sytuację Herburta zmieni konwokacja krakowska, której obrady trwały od kwietnia do czerwca 1608 r. $^{73}$ Do Krakowa przybyło 20 przedstawicieli senatu (poza Mikołajem Zebrzydowskim i Zygmuntem Grudzińskim, wojewoda rawskim). Obrady rozpoczęły się 28 kwietnia podaniem przez króla porządku obrad ${ }^{74}$. Trzy pierwsze punkty poświęcone zostały rokoszowi: sposobom na opanowanie sytuacji wewnętrznej, uspokojeniu nastrojów społecznych, propozycji królewskiej dla rokoszan pragnących pojednania z władcą oraz metodom działania wobec oddziałów wojskowych, które pustoszyły kraj. Znalazło to odzwierciedlenie w dalszych dokumentach ${ }^{75}$. Do propozycji królewskiej odnieśli się zgromadzeni senatorowie ${ }^{76}$. Zaproponowano napisanie listu do wojewody krakowskiego, w którym zawarte byłoby zaproszenie na konwokację. Pozostałych rokoszan postanowiono „do łaski królewskiej wezwać przez edykt”"77. Senatorowie przygotowali również dokument, w którym podano warunki do spełnienia przez Zebrzydowskiego $^{78}$. Został do niego wysłany z listem Piotr Ożga, pisarz lwowski, który miał zabiegać o jak najszybsze przybycie wojewody do Krakowa. Istniało zagrożenie, że ze względu na stan zdrowia nie będzie on mógł przyjechać na konwokację. Tak też się stało. Ożga wrócił jedynie z listem od wojewody, w którym nie podano konkretnej daty przybycia do Krakowa. 20 maja senatorowie postanowili, że będą oczekiwać na przywódcę rokoszan do 29 maja. Jeśli nie doszłoby do spotkania, wówczas miały rozpocząć

70 B. Czart., 104, nr 109, Respons na te ceduke, b.m. i d., [ok. 1608 r.], k. 517.

$71 \quad$ Ibidem, k. 517.

72 Ibidem, k. $517 \mathrm{v}$.

73 Akta tej konwokacji zachowały się w kilku odpisach, w niniejszym artykule korzystałam z kopii znajdującej się w Bibliotece Naukowej im. Zielińskich Towarzystwa Naukowego Płockiego [dalej cyt.: TNP BZ], 115: Convocatio babita Cracoviae, 1608, 115, k. 236-254v.

74 B. Czart., 341, Punkta propositiej KJmci w tajemnej radzie, s. 1033.

75 Ibidem, Podane od Jego Królewskiej Mości sposoby do prayjecia w taskę pana wojewody krakowskiego, s. 890-892; ibidem, Uniwersat pana hetmana koronnego do ludzi bawiacych sie kupami bę stużby po ksiestwie mazowieckim, s. 925 .

76 Ibidem, 104, Konkluæija na te punkta propositiej KJmci, s. 121-122.

77 Ibidem, s. 121.

78 TNP BZ, 115, Środki przez któryby JEM pan wojewoda krakowski do taski JEKM miat prayjjść przęz pany senatory moderowane, k. 238v-239v. 
się kolejne dyskusje nad sposobami opanowania sytuacji w Rzeczypospolitej ${ }^{79}$. Zastanawiano się równiė̇, „co czynić z więźniami na zamku krakowskim będącymi”80. Podjęto decyzję o uwolnieniu Pękosławskiego, natomiast „Pana Herborta, o którym jest scyssia niemała, z pany cudzoziemskiemi o królestwo praktykował, do sejmu zatrzymać"81. Zebrzydowski nie stawił się w Krakowie również 29 maja. Do miasta zaczęły napływać informacje, że wojewoda zbliża się w otoczeniu swoich żołnierzy, dlatego w jego stronę wyjechał hetman polny, aby go upomnieć i poinformować o spotkaniu z Zygmuntem III 6 czerwca o godzinie 9.00 rano $^{82}$. Przywódca opozycji przybył tego dnia do dawnej stolicy i doszło do ucałowania ręki królewskiej oraz licznych przemówień senatorów zgromadzonych na tej uroczystości ${ }^{83}$.

Zapanowała ogólna radość i ulga z powodu uspokojenia sytuacji w kraju. Jan Krajewski w okolicznościowym utworze nazywał króla „niezwyciężonym”, który spojrzał miłosiernie na poddanych i dzięki swojej łaskawości doprowadził do zakończenia waśni w społeczeństwie. Podkreślona została również dobra rada senatorów, a wszystko to było wynikiem Boskiej interwencji ${ }^{84}$. Nie dotyczyło to jednak więźniów z Krakowa, którzy w odosobnieniu przebywali aż do końca 1608 r. W tym samym czasie w obronie Herburta wypowiedział się sejmik proszowicki, zapowiadając wstawiennictwo podczas zbliżającego się sejmu walnego w Warszawie ${ }^{85}$.

Zanim przejdę do omówienia wydarzeń związanych z tą sprawą w 1609 r., chciałabym poruszyć kwestię dotyczącą utworu Strzała z saydaka, która Korona Polska [...] z cięzkiego wiezienia swego do dziatek swych stanu rycerskiego wypuscita ${ }^{86}$, który moim zdaniem mógł powstać w okresie więzienia Herburta w krakowskiej wieży. Dotychczas za L. Szczerbicką przyjmowano, że Herburt napisał ów utwór zaraz po bitwie guzowskiej. Jednak po analizie zdarzeń, które nastapiły po przegranej rokoszan (wycofanie się Szczęsnego z pola walki, udanie się pod Lublin, zbieranie sił i środków na kontynuowanie walki, ucieczka na Wołyń do majątku teścia, wreszcie pojmanie go w Tajkurach 18 lipca), jest to raczej niemożliwe. Historycy i literaturoznawcy nie poświęcali mu wiele uwagi ${ }^{87}$. Niewątpliwie

\footnotetext{
79 Ibidem, Convocatio habita..., k. 241v.

80 Ibidem, k. 241.

81 Ibidem, k. 241v.

82 Ibidem, k. 250v.

83 Ibidem, k. 250v-253v.

84 J. Krajewski, Zgoda i pokój, [w:] Pisma polityczne..., t. 1, s. 349-356.

85 Instrukcja dana postom na sejm z. sejmiku województwa krakowskiego w Proszowicach, 13 XII 1608 r., [w:] Akta sejmikowe wojewódz̨twa krakowskiego, wyd. S. Kutrzeba, Kraków 1932, s. 337. B. Czart., 360, Strzała z saydaka..., s. 348-362. Druk w: Pisma polityczne..., t. 2, Kraków 1917, s. 162-169.

87 Uczynili to jedynie: L. Szczerbicka, op. cit., s. 243-247; J. Nowak-Dłużew ski, Okolicznościowa poezja polityczna w Polsce. Zygmunt III, Warszawa 1971, s. 182 oraz M. Wi ch owa, Jana Szczesnego Herburta „Strzata, która Korona Polska... do dziatek swych stanu sqlacheckiego wypuscita”: dzieto publicystyczne z. czasón
} 
utwór stanowił gorzką refleksję po przegranej bitwie. Na jego powstanie już podczas pobytu w więzieniu wskazują słowa: ,przy tym ich obtoczył tak twardym murem, że się im o tym nie tylko pytać, ale też przeciw temu i bąknąć nie wolno, bo gotową szubienicą płacą"88. Utwór miał przede wszystkim pokrzepić przeciwników Zygmunta III i zachęcić do dalszego oporu mimo poniesionej klęski w starciu z wojskami królewskimi. Krytyka polityki władcy, jego otoczenia, patetyczne i bardzo emocjonalne określenia ojczyzny targanej wewnętrznym konfliktem sugeruja, że Strzała... została napisana w pierwszych dniach pobytu Herburta w więzieniu i miała stanowić wskazówki dalszego postępowania dla znajdujących się na wolności rokoszan.

Starosta dobromilski w czasie oczekiwania na sejm walny nie pozostał bierny. Wysłał kolejną prośbę o wstawiennictwo do królowej Konstancji ${ }^{89}$, zaś jego żona planowała odbić go z krakowskiego więzienia ${ }^{90}$. Te starania również zakończyły się fiaskiem i Herburt pozostał w niewoli aż do sejmu pacyfikacyjnego, który rozpoczął obrady 15 stycznia i trwał do 26 lutego 1609 r. ${ }^{91}$ Królowi zależało na uspokojeniu sytuacji w kraju w związku z jego planami ekspansji na wschód. W uchwalonej na sejmie konstytucji pt. „Amnistya” deklarowano w imieniu Zygmunta III:

Iż chociaż My od niektórych obywatelów państw Naszych z różnych miar w dostojeństwie Naszym są urażeni, spolnej Ojczyźnie darujemy i onych in perpetuum zapominamy i uniwersały przeciw nim eonomine wydane podnosimy. Tak, iż żaden z tych, którzy wypowiedziane posłuszeństwo przystojnym Nam przeproszeniem znowu oddali i drudzy tymże sposobem za podaniem Naszym oddawać jako i insi powinni będa, o żadne zjazdy przeszłe i ludzi do kupy zwabiania ani o żaden inszy przeciw Nam i dostojeństwu Naszemu postępek, ani od Nas samych, ani od kogo inszego nijakim sposobem ruszani być nie mają wiecznymi czasy ${ }^{92}$.

rokoszu Zebraydowskiego i jego funkcie komunikacyjne w procesie odbioru, „Napis. Pismo poświęcone literaturze okolicznościowej i użytkowej" 2006, nr 12, s. 89-98.

88 Pisma politycrne..., t. 2, s. 166.

89 Biblioteka Zakładu Narodowego im. Ossolińskich we Wrocławiu [dalej cyt.: B. Ossol.], 231, Suplika Pana Szczęsnego Herburta, gdy siedział w więzieniu o rokosz w Krakowie do Królowej Jej Mci, s. 276277.

90 Archiwum Główne Akt Dawnych w Warszawie [dalej cyt.: AGAD], Archiwum Publiczne Potockich [dalej cyt.: APP] 7, Zygmunt III do S. Lubomirskiego, Warszawa 17 I 1609 r., k. 237.

91 Wstep, [w:] Volumina Constitutionum [dalej cyt.: VC], t. 2, cz. 2: 1587-1609, oprac. S. Grodziski, Warszawa 2008, s. 378.

92 Ibidem, s. 379. 
Te postanowienia nie dotyczyły Szczęsnego. Jego uwolnienie obwarowane zostało przez króla specjalnymi warunkami przedstawionymi w edykcie z 24 lutego ${ }^{93}$. Najważniejszy z nich dotyczył groźby poddania go sądowi sejmowemu za obrazę majestatu królewskiego, jeśli nie zaprzestanie swojej działalności przeciwko monarsze. Wynika z tego, że podczas obrad sejmu w 1609 r. żaden sąd sejmowy nad Herburtem się nie toczył. Zygmunt III nakazywał również staroście dobromilskiemu natychmiastowy powrót do jego zamku i nakładał na niego areszt domowy na okres dwóch lat. Nie mógł on swobodnie przemieszczać się nawet w obrębie ziemi przemyskiej. Edykt zezwalał jedynie na opuszczanie zamku dobromilskiego na odległość siedmiu mil. W tym czasie Herburt miał zakończyć stare spory i nie wdawać się w nowe konflikty z sąsiadami oraz nie dążyć do zemsty na swoich wrogach. Zakazano mu również utrzymywania kontaktów z zagranicą i gromadzenia oddziałów zbrojnych. Ponadto edykt zakazywał mu wysyłania sług poza granice Rzeczypospolitej, utrzymywania jakiejkolwiek korespondencji z państwami ościennymi i szukania zemsty na rotmistrzach odpowiedzialnych za jego uwięzienie. Celem Zygmunta III było wszechstronne zabezpieczenie się przed groźbą dalszych kontaktów Herburta z Gabrielem Batorym i wyłączenie go z bieżącej działalności politycznej, przynajmniej na szczeblu lokalnym.

Zaprzysiężenie powyższych warunków i oficjalne przeprosiny rokoszanina nastąpiły 20 marca 1609 r. Nieprzypadkowe było symboliczne miejsce tej uroczystości: odbyła się ona przed grobem św. Stanisława w katedrze na Wawelu. W zamyśle króla ceremonia miała oznaczać ponowne połączenie się społeczeństwa polsko-litewskiego, tak jak ongiś dzięki opiece świętego doszło do zjednoczenia ziem polskich po rozbiciu dzielnicowym. Ceremonia wzbudzała również zaciekawienie współczesnych. Jej opis znany jest $z$ wielu odpisów ${ }^{94}$. Niewattpliwie był to jeden z istotniejszych momentów pacyfikacji kraju: przed królem korzył się jeden z głównych przywódców rokoszu, który wyjątkowo długo odczuwał gniew władcy. Herburt w pięknych słowach zapewniał króla o swojej wierności i chęci służenia monarsze oraz Rzeczypospolitej. Przekonywał ponownie, że dobro ojczyzny leży mu głęboko na sercu i pragnienie reformy państwa było powodem jego wstąpienia w szeregi rokoszan. Zwracał się również do Boga, który tak ciężko go doświadczał w ostatnich latach. Wierzył jednak, że teraz zły los się od niego odwróci i będzie miał szansę na odkupienie swoich win: „pod niebytność WKMci zdrowie swe przeciwko każdemu nieprzyjacielowi WKMci gotów postawić, czego świadkiem mam Boga" 95 .

93 B. Czart., 1577, Akt zwalniający Jana Szczęsnego Herburta z więzienia, Warszawa 24 II 1609 r., s. 184186.

94 Ibidem, 375, k. 776-777.

95 Ibidem, 104. M.in.: Przysięga przez Pana Herburta przed Panem referendarzem koronnym uczyniona die 20 martii przed grobem Ś. Stanisława, s. 641. 
Ceremonia ta, choć niezakończona ucałowaniem ręki królewskiej, kończyła więzienny epizod w życiu Herburta. Niedaleka przyszłość miała pokazać, jak niewiele warte sa wzruszające słowa przysięgi składanej Bogu i królowi przed grobem patrona ojczyzny. Były rokoszanin traktował to wydarzenie czysto koniunkturalnie. Było ono dla niego przepustką z krakowskiego więzienia i szansą na powrót do aktywnej polityki, mimo ostrzeżeń zawartych w edykcie królewskim. Dalsze poczynania Szczęsnego dobitnie świadczą, że więzienie nie zmieniło jego światopoglądu ani nie uspokoiło jego charakteru. Niewola odcisnęła swoje piętno na jego psychice. Jak trafnie zauważył Władysław Łoziński, klęska jego politycznych ideałów, upokarzające pojmanie i doświadczenia więzienne, przede wszystkim zaś widmo utraty życia, spowodowały zwrot Herburta w kierunku mistycyzmu ${ }^{96}$. Widomym znakiem tej zmiany był nie tylko kontakt $z$ astrologiem Marcinem z Klecka, ale również sny nawiedzające go w ostatnich dniach niewoli. Opisał je w liście do kanonika warmińskiego Tomasza Tretera ${ }^{97}$.

Podsumowując powyższe ustalenia, warto zastanowić się nad kilkoma kwestiami. Dlaczego jedynie Herburta i Pękosławskiego spotkała tak surowa kara ze strony króla? Więzienie i widmo zapłacenia najwyższej ceny za ideały rokoszowe musiały być dla obu szlachciców niezwykle przygnębiające, zwłaszcza w porównaniu z pozostałymi przywódcami rokoszu. Wpływ na decyzję Zygmunta III miało kilka czynników. Niewątpliwie najpoważniejszym wśród licznych grzechów Herburta było oskarżenie go o zdradę stanu i spiskowanie z księciem siedmiogrodzkim. Jednak, jak już wspomniałam, rzekomych dowodów na te spiski nigdy nie upubliczniono. Na niekorzyść Herburta działały węgierskie zaciagi, z którymi przystąpił do rokoszu, oraz warunki postawione mu przez króla w edykcie zwalniającym go z więzienia. Duża aktywność w czasie rokoszu, m.in. podczas zjazdów, i publicystyczne ataki na monarchę mogły spowodować osobistą urazę króla i chęć ukarania rokoszanina. W aneksie do konstytucji o amnestii znajduje się fragment, który bez wątpienia odnieść można do literackiej działalności Herburta, jednak władca postanowił ze względu na ,zacność urodzenia z familii starych i rodowitych, zasługi Rzeczypospolitej znaczne i przystojne życie privatim et publice bez przygany"98 puścić je w niepamięć.

Utrzymanie autorytetu władcy wymagało ukarania przedstawiciela opozycji. Symboliczną ofiarą okazał się starosta dobromilski. Był postacią powszechnie znana, wyróżniał się podczas licznych wystapień rokoszowych, jednak ustępował godnościami i majątkiem takim postaciom jak Mikołaj Zebrzydowski czy Janusz Radziwiłł. Po powrocie do

96 W. Loziński, Prawem i lewem. Obyczaje na Czerwonej Rusi w pierwszej połowie XVII wieku, oprac. J. Tazbir, Warszawa 2005, s. 452.

97 B. Czart., 1577, J.S. Herburt do Tomasza Tretera, b.m. i d. [po 1609 r.], k. 202-204.

98 VC, t. 2, cz. 2, „Amnistya”, s. 379. J. Serafin, Jan Szczusny Herburt (1567-1616). Dzialacz szlachecki, pisarz polityczny, wydawca, Sanok 2017, s. 149. 
Dobromila pisał do Krzysztofa Radziwiłła podziękowania za pomoc okazana podczas ostatniego sejmu, co bardzo pomogło w jego uwolnieniu99. Dalsza działalność Herburta po uwolnieniu z więzienia to temat na osobne rozważania. Dość powiedzieć, że jego żal i skrucha były krótkotrwałe i wyłącznie koniunkturalne.

\section{Bibliografia}

\section{Źródła rękopiśmienne:}

Archiwum Główne Akt Dawnych w Warszawie, Archiwum Publiczne Potockich, 7. Archiwum Narodowe w Krakowie, Archiwum Sanguszków, teka XXVII, koperta 28. Biblioteka Książąt Czartoryskich w Krakowie, 104, 341, 360, 375, 1577, 2580. Biblioteka Narodowa w Warszawie, 3087.

Biblioteka Naukowa im. Zielińskich Towarzystwa Naukowego Płockiego, 115.

Biblioteka Zakładu Narodowego im. Ossolińskich we Wrocławiu, 231.

\section{Źródła drukowane:}

Akta sejmikowe województwa krakonskiego, wyd. S. Kutrzeba, Kraków 1932.

Cilli A., Historia buntów możnowładcsych w Polsce w latach 1606-1608. Historia Moskwy, przeł. A. Broczkowska-Nguyen, oprac. i wyd. J. Byliński, W. Kaczorowski, Opole 2012.

Korespondencja Jerzego Zbaraskiego, [w:] „Scriptores Rerum Polonicarum”, t. 5, wyd. A. Sokołowski, Kraków 1880.

Listy staropolskie z epoki Wazów, oprac. H. Malewska, Warszawa 1959.

Lubieński S., Droga do Szwecji Zygmunta III, króla polskiego i szpwedzkiego, w 1593 roku. Rozrucby domowe $w$ Polsce w latach 1606-1608, przeł. A.B. Jocher, S. Szczygieł, wyd. J. Byliński, W. Kaczorowski, Opole 2009.

Machiavelli N., Ksiaż̧, przeł. C. Nanke, Warszawa 1999.

Miaskowski K., Zbiór rytmów, wyd. K.J. Turowski, Kraków 1861.

Piasecki P., Kronika Pawła Piaseckiego biskupa przemyślskiego, wyd. J. Bartoszewicz, Kraków 1870.

Pisma polityczne z. çasów rokoszu Zebraydowskiego 1606-1608, wyd. J. Czubek, t. 1-3, Kraków 19161918.

Pisma Stanistawa Żótkiewskiego kanclerza koronnego i hetmana, wyd. A. Bielowski, Lwów 1861.

Radziwiłł A.S., Rys panowania Zygmunta III, wyd. J. Byliński, W. Kaczorowski, Opole 2011.

Volumina Constitutionum, t. 2, cz. 2: 1587-1609, oprac. S. Grodziski, Warszawa 2008.

\section{Literatura przedmiotu:}

Augustyniak U., Myszkowski (Myszkowski-Gonzaga margrabia na Mirowie) Zygmunt, [w:] Polski stownik. biograficzny, t. 22, Warszawa 1977, s. 404-407.

Augustyniak U., Wazowie i królowie rodacy. Studium władży królewskiej w Rz̨eçypospolitej XVII wieku, Warszawa 1999.

Bibliografia Literatury Polskiej-Nowy Korbut, t. 2, Pismiennictwo Staropolskie, red. R. Pollak, Warszawa 1964.

99 B. Czart., 2580, J.S. Herburt do Krzysztofa Radziwiłła, Mościska 5 IV 1609 r., k. 307. 
Biliński W., Lipko M., Pekostawski Prokop (? - po lutym 1609 r.), [w:] Polski stownik biograficzny, t. 25, Wrocław 1980, s. 740-742.

Byliński J., Rokoszowe koncepcje reformy państwa (1606-1608), [w:] Studia historyczno-prawne. Ksiega poswiecona pamieci Profesora Jana Seredyki, red. W. Kaczorowski, Opole 2008, s. 59-106.

Byliński J., Antyregalistyczna propaganda w czasach rokoszu Zebraydowskiego (1606-1608), [w:] Na obrzeżach polityki, cz. 1, red. M. Kosman, Poznań 2002, s. 15-34.

Cynarski S., Herburt Jan Szczesny (1567-1616), [w:] Polski stownik biograficzny, t. 9, Wrocław 19601961, s. 443-445.

Cynarski S., Herburt Walenty (1524-1572), [w:] Polski stownik biograficzny, t. 9, Wrocław 1960-1961, s. 453-454.

Dobrowolska W., Mtodość Jerzego i Krzysztofa Zbaraskich (Ze wstepem o rodzie Zbaraskich i życiorysem Janusza Zbaraskiego wojewody bractawskiego), „Rocznik Przemyski”, 1927, s. 7.

Dziama L., Zapatrywania polityczne Kaspra Miaskowskiego (na podstawie jego „Rytmów”), „Roczniki Towarzystwa Przyjaciół Nauk Poznańskiego”, 1895, 21, s. 107-124.

Grabowski R.F., Guгów 5 VII 1607 r., Zabrze 2005.

Jung D., Wierszopisowie Ktecka w latach 1590-1623. Praycsynki do historii kultury staropolskiej, Kłecko-Gniezno 2012, Biblioteka Staropolska, t. 1.

Łoziński W., Prawem i lewem. Obyczaje na Czerwonej Rusi w pierwszej potowie XVII wieku, oprac. J. Tazbir, Warszawa 2005.

Maciszewski J., Sejm 1607 r. a załamanie sie planów reformy państwa, [w:] O naprawe Rzeczypospolitej XVII-XVIII w. Prace ofiarowane Wtadystawowi Czaplinskiemu w 60 rocznice urodzin, red. J. Gierowski et al., Warszawa 1965, s. 37-47.

Maciszewski J., W przededniu bitwy guzowskiej, [w:] $Z$ dziejów wojny i polityki, red. S. Herbst et al., Warszawa 1964, s. 179-189.

Maciszewski J., Wojna domowa w Polsce (1606-1609), Cześś I. Od Steżycy do Janowca, Wrocław 1960, Prace Wroctawskiego Towarzystwa Nankowego. Seria A.

Nowak-Dłużewski J., Okolicz̧nościowa poezja politycz̧na w Polsce. Zygmunt III, Warszawa 1971.

Opaliński E., Dwa nieznane projekty ",procesu” konfederacji warszawskiej z 1605 i 1607 roku, „Res Historica” 2000, z. 10: Z driejów stosunków nyznanionych w Rzecsypospolitej XVI-XVII wieku, s. 165-177.

Opaliński E., Zjazd rokoszowy w Jedrzejowie w roku 1607, [w:] Król a prawo stanów do oporu. Materiaty konferencji naukowej zorganizowanej przez. Zamek Królewski na Wawelu, Instytut Historii Polskiej Akademii Nauk, Instytut Historii Uniwersytetu Jagiellonskiego, Instytut Historii Uniwersytetu Ślaskiego w dniach 4-6 października 2006, red. M. Markiewicz, E. Opaliński, R. Skowron, Kraków 2010, s. 221-236.

Opaliński E., Zjazd rokoszowy warszawski w październiku 1607 r., „Kwartalnik Historyczny” 2014, R. 121, s. 521-539.

Pawłowska-Kubik A., Od wypowiedzenia postuszeństwa Zygmuntowi III (24 VI 1607) do sejmu pacyfikacyjnego (1609). Rzeczpospolita na politycznym rozdrożu, Torun 2016.

J. Serafin, Jan Szczesny Herburt (1567-1616). Dziatacz sælachecki, pisarzpolityczny, wydawca, Sanok 2017, s. 149.

Sokołowski A., Jan Szczesny Herburt, pierws zy wydawca Kroniki Dtugoszowej, „Biblioteka Warszawska", 1883, t. 2-3.

Szczerbicka L., Jan Szczesny Herburt. Zarys monografii, [w:] Ze studión nad literatura staropolska, red. K. Budzyk, Wrocław 1957, s. 205-290, Studia Staropolskie.

Trybunat Koronny w kulturze prawnej Rzeczypospolitej szlacheckiej, red. W. Bednaruk, A. Dębiński, M. Lipska, Lublin 2008. 
Wichowa M., Jana Szczesnego Herburta „Strzała, która Korona Polska... do dziatek swych stanu szlacheckiego wypuścita”: dzieto publicystyczne z czasów rokoszu Zebryydowskiego i jego funkcje komunikacyjne w procesie odbioru, „Napis. Pismo poświęcone literaturze okolicznościowej i użytkowej” 2006, 12, s. 89-98.

Wisner H., W imie praw i zwyczajów, cazyli wbrew nim. Rokosz Zebraydowskiego 1606-1607, [w:] Król a prawo stanów do oporu. Materiały konferencji naukowej zorganizowanej przez Zamek Królewski na Wawelu, Instytut Historii Polskiej Akademii Nauk, Instytut Historii Uniwersytetu Jagiellonskiego, Instytut Historii Uniwersytetu Ślaskiego w dniach 4-6 października 2006, red. M. Markiewicz, E. Opaliński, R. Skowron, Kraków 2010, s. 209-219.

Wisner H., Rokosz Zebraydowskiego, Warszawa 1989.

Zarzycki W., Temida sejmowa. Z dziejów sqdu sejmowego w Polsce przedrozbiorowej, Warszawa 2000.

Żelewski R., Jan Herburt h. własnego (1524-1577), [w:] Polski stownik biograficzny, t. 9, Wrocław 19601961, s. 440-442. 